\title{
РІЗНІ РІВНІ ЗМІШАНОЛІГАНДНОГО КОМПЛЕКСУ ЦИНКУ, МАНГАНУ Й КОБАЛЬТУ В ГОДІВЛІ ВИСОКОПРОДУКТИВНИХ КОРІВ ГОЛШТИНСЬКОЇ ПОРОДИ НІМЕЦЬКОӦ СЕЛЕКЦІЇ ТА ÏХ ВПЛИВ НА СПОЖИВАННЯ КОРМІВ, ПРОДУКТИВНІСТЬ, ВИТРАТИ КОРМУ, ВІДТВОРНІ ФУНКЦІЇ ТА ГЕМАТОЛОГІЧНІ ПОКАЗНИКИ
}

\author{
Кропивка Юрій Григорович \\ кандидат сільськогосподарських наук, доцент \\ Львівський національний університет ветеринарної медицини \\ та біотехнології імені С. 3. Ґжицького \\ ORCID: 0000-0002-4654-0147 \\ E-mail: yurikropyvka@gmail.com
}

\author{
Бомко Віталій Семенович \\ доктор сільськогосподарських наук, професор \\ Білоцерківський національний аграрний університет \\ ORCID: 0000-0001-5558-6924 \\ E-mail: godivlya@ukr.net
}

У статті представлені результати вивчення впливу різних доз змішанолігандних комплексів Цинку, Мангану і Кобальту в годівлі високопродуктивних корів голштинської породи німецької селекції на показники споживання кормів, молочної продуктивності за перші 100 днів лактації, відтворні функції та гематологічні показники. Встановлено, що менші дози Цинку, Мангану й Кобальту покращили споживання кормосуміші піддослідними коровами. У середньому за дослід корови 1-ї контрольної групи поїдали 53,4 ке кормосуміші, корови 2-ї дослідної групи - 54,5 ке, 3-ї - 58,2 ке, 4-ї - 55,7 кә і 5-ї - 52,8 ке. Середньодобові надої й надії молока за перші 100 днів лактації змінювалися залежно від надходження Цинку, Мангану й Кобальту до організму піддослідних корів. Найнижчі надої натурального молока за перші 100 днів лактації мали корови 5-ї дослідної групи, де концентрація мікроелементів в 1 ке СР кормосуміші була найнижчою й складала, ме: Цинку 42,6; Мангану - 42,6 і Кобальту - 0,55. Надої натурального молока корів 1-ї контрольної, 2-ї, 3-ї й 4-ї дослідних груп були вищими від надої корів 5-ї дослідної групи на 106,3 \%, 106,2; 113,6 і 108,8 \% відповідно. Вміст жиру в молоці корів 5-ї дослідної групи становив у середньому 3,57 \%, тоді, як у молоці корів 1-ї контрольної, 2-ї, 3-ї й 4-ї дослідних груп він був вищим на 0,01-0,05 \%. Більш високі концентрації мікроелементів позитивно вплинули на тривалість сервіс-періоду і в піддослідних тварин 1-ї контрольної, 2-ї, 3-ї і 4-ї дослідної груп він був коротшим на 14,0; 16,2; 30,3 і 10,9 днів відповідно. На одне плодотворне осіменіння кожної корови 1-ї контрольної групи знадобилось провести 1,5 запліднення, у 2-й дослідній - 1,6; у 3-й дослідній - 1,4; у 4-й дослідній - 1,6 і в 5-й дослідній - 1,9 запліднення. Аналіз гематологічних показників піддослідних корів свідчить, що змішанолігандні комплекси Цинку, Мангану й Кобальту в складі концентрованих кормів мають позитивний вплив на організм лактуючих корів, що, у свою чергу, поліпшує їх продуктивність і особливо відтворні фрункції. Найефективнішою виявилась доза змішанолігандних комплексів Цинку, Мангану й Кобальту з концентрацією в 1 ке СР кормосуміші, ме: Цинку - 54,7; Мангану - 54,7 і Кобальту - 0,7.

Ключові слова: високопродуктивні корови, молочна продуктивність, відтворювальна функція, гематологічні показники, мікроелементи, змішанолігандний комплекс.

DOI: https://doi.org/10.32845/bsnau.Ivst.2020.4.16

У дійних корів через десріцит Цинку, Мангану, Кобальту й Селену в раціонах, знижується перетравність поживних речовин, особливо грубих і соковитих кормів, а через зниження інтенсивності ферментативних процесів у передшлунках відбувається зменшення доступності енергії кормів та ефективності її використання на виробництво тваринницької продукції і функцію відтворення.

Життєдіяльність, рівень обмінних процесів, резистентність, продуктивність, відтворна здатність корів залежать, поряд із генетичними задатками та мінеральним живленням, від надходження із зовнішнього середовища 3 кормами біологічно активних речовин [1, 2, 3, 4, 5], які сприяють інтенсифікації обмінних процесів в організмі тварин, ефективному засвоєнню поживних речовин кормів, тобто трансформації їх у продукцію $[6,7,8]$.

Біологічно активні речовини стимулюють і регулюють процеси глибоких хімічних перетворень в організмі тварин органічних і мінеральних речовин кормів, що входять до складу раціонів. Такими речовинами є білки-фрерменти, які в

мільйони разів прискорюють хімічні реакції в організмі і до складу яких, крім білків входять мікроелементи та вітаміни, що надходять з кормами та преміксами. За відсутності окремих мікроелементів чи вітамінів або при надходженні недостатньої їх кількості, активність ферментів знижується, що стає причиною порушення обміну речовин в організмі тварини, погіршення стану її здоров'я, зниження продуктивності та відтворювальної здатності $[9,10]$. Уведення в раціони корів мікроелементів без урахування фактичного їх вмісту в кормах нерідко $є$ причиною зайвої витрати кормів, зниження їх продуктивності, порушення їх репродуктивних функцій, підвищення сприйнятливості до захворювань і зменшення строків їх експлуатації $[11,12,13]$ через їх надлишок $[14,15$, 16], який проявляється через деякий період часу.

Тому метою роботи було вивчення есрективності використання різних рівнів змішанолігандного комплексу Цинку, Мангану й Кобальту в годівлі високопродуктивних корів голштинської породи німецької селекції.

Матеріали та методи досліджень. Корів для дослі-

Вісник Сумського національного аграрного університету 
ду в ТОВ «Терезине» Білоцерківського району Київської області відбирали в кінці першої лактації за десятьп'ятнадцять днів до розтелення за принципом аналогів 3 врахуванням віку, походженням, дати плодотворного осіменіння, живої маси й молочної продуктивності за першу лактацію. Усі відібрані корови-аналоги були чистопородні, мали схожу продуктивність матерів, середню вгодованість та були клінічно здоровими, утримувались в однакових умовах і одночасно були завезені нетелями в господарство з Німеччини. Корів було розділено на п'ять груп: одну контрольну і чотири дослідні. Контролем служила оптимальна доза змішанолігандних комплексів Цинку, Мангану й Кобальту, яка була встановлена в попередньому досліді з концентрацією в 1 кг сухої речовини (СР) кормосуміші (КС), мг: Цинку - 60,8; Мангану - 60,8 і Кобальту - 0,78. Для 2-ї дослідної групи концентрацію цих мікроелементів збільшили на $10 \%$, а в 3-й - навпаки зменшили на цю кількість. Стосовно 4-ї і 5-ї дослідних груп, то концентрацію в 1 кг СР кормосуміші Цинку, Мангану й Кобальту зменшили на 20 і 30 \% відповідно, порівняно з контролем. Схема досліду наведена в таблиці 1.

\section{Схема науково-господарського досліду, $\mathrm{n}=10$}

Таблиця 1

\begin{tabular}{|c|c|}
\hline Група & Досліджуваний фактор \\
\hline 1 контрольна & $\begin{array}{l}\text { КС + змішанолігандні комплекси Цинку, Мангану, Кобальту + Суплекс Se й сульфат купруму та йодит калію. } \\
\text { В } 1 \text { кг СР міститься, мг: Цинку - 60,8; Мангану - 60,8; Кобальту - 0,78; Селену - 0,3; Купруму - } 12 \text { і Йоду - 1,1. }\end{array}$ \\
\hline 2 дослідна & $\begin{array}{l}\text { КС + змішанолігандні комплекси Цинку, Мангану, Кобальту + Суплекс Se й сульфат купруму та йодит калію. } \\
\text { В } 1 \text { кг СР міститься, мг: Цинку - 66,9; Мангану - 66,9; Кобальту - 0,86; Селену - 0,3; Купруму - } 12 \text { і Йоду - 1,1. }\end{array}$ \\
\hline 3 дослідна & $\begin{array}{l}\text { КС + змішанолігандні комплекси Цинку, Мангану, Кобальту + Суплекс Se й сульфрат купруму та йодит калію. } \\
\text { В } 1 \text { кг СР міститься, мг: Цинку - 54.7: Мангану - 54,7; Кобальту - 0.7: Селену - 0,3: Купруму - } 12 \text { і Йоду - } 1.1 .\end{array}$ \\
\hline 4 дослідна & $\begin{array}{l}\text { КС + змішанолігандні комплекси Цинку, Мангану, Кобальту + Суплекс Sе й сульфат купруму та йодит калію. } \\
\text { В } 1 \text { кг СР міститься, мг: Цинку - 48,6; Мангану - 48,6; Кобальту - 0,62; Селену - 0,3; Купруму - } 12 \text { і Йоду - } 1,1 .\end{array}$ \\
\hline 5 дослідна & $\begin{array}{l}\text { КС + змішанолігандні комплекси Цинку, Мангану, Кобальту + Суплекс Se й сульфрат купруму та йодит калію. } \\
\text { В } 1 \text { кг СР міститься, мг: Цинку - 42,6; Мангану - 42,6; Кобальту - 0,55; Селену - 0,3; Купруму - } 12 \text { і Йоду - } 1,1 .\end{array}$ \\
\hline
\end{tabular}

Піддослідних корів у підготовчий період, який збігався з сухостійним періодом годували малокомпонентними кормосумішками, до складу яких уводили: сіно вико-вівсяне - 4 кг, сінаж злаково-бобовий - 10 кг, силос кукурудзяний 25 кг, мелясу - 2 кг, комбікорм-концентрат - 3,5 кг, сіль кухонну - 0,19 кг, знефторений фоссрат - 0,18 кг. Після розтелу піддослідним лактуючим коровам поступово сіно вико-вівсяне замінили на люцернове й у кормосуміші збільшували кормову даванку концентрованих кормів, які також згодовували у вигляді комбікорму-концентрату.

Отримувані тваринами корми як у сухостійний так і в період лактації були дефіцитними на Цинк, Купрум, Кобальт, Манган, Йод та Селен. Для покриття дефіциту у вище вказаних мікроелементах для корів контрольної і дослідних груп уводили в комбікорми-концентрати премікс з різними дозами змішанолігандних комплексів Цинку, Мангану й Кобальту. Дефіцит Купруму покривали за рахунок його сульфату, а десріцит у Селені - за рахунок Суплексу Селену, з розрахунку 0,3 мг/кг сухої речовини.

Результати досліджень. У продовж перших 100 днів лактації піддослідним коровам згодовували кормосуміш. Так як корови були на першому місяці лактації, проводили їх роздій. Авансовану годівлю здійснювали за рахунок комбікорму-концентрату. У складі комбікорму містилися концентровані корми, а також знефторений фосфрат, сіль кухонна й премікс. Середнє споживання кормосуміші за перших 100 днів лактації наведено в таблиці 2.

Таблиця 2

Споживання кормосуміші піддослідними коровами та кількість спожитих поживних і біологічно активних речовин

\begin{tabular}{|c|c|c|c|c|c|}
\hline \multirow{2}{*}{ Корми, кг } & \multicolumn{5}{|c|}{ Група тварин } \\
\hline & 1 контрольна & 2 дослідна & 3 дослідна & 4 дослідна & 5 дослідна \\
\hline Кормосуміш & 53,4 & 54,5 & 58,2 & 55,7 & 52,8 \\
\hline \multicolumn{6}{|c|}{ У раціоні міститься: } \\
\hline Кормові одиниці & 31,3 & 31,9 & 34,3 & 32,9 & 30,9 \\
\hline Обмінна енергія, МДж & 318,8 & 325,4 & 347,5 & 332,5 & 315,0 \\
\hline Суха речовина, кг & 27,7 & 28,3 & 30,2 & 28,9 & 27,4 \\
\hline Сирий протеїн, г & 5327,7 & 5437,5 & 5806,6 & 5557,2 & 5267,7 \\
\hline Перетравний протеїн, г & 4047,7 & 4131,1 & 4411,6 & 4222,1 & 4002,4 \\
\hline Сира клітковина, г & 5500,9 & 5665,3 & 6049,9 & 5790,0 & 5488,8 \\
\hline Крохмаль, г & 5358,7 & 5469,1 & 5840,4 & 5589,5 & 5298,5 \\
\hline Цукор, г & 2228,9 & 2274,8 & 2429,3 & 2324,9 & 2204,1 \\
\hline Сирий жир, г & 1219,7 & 1244,8 & 1329,3 & 1272,2 & 1205,9 \\
\hline Кальцій, г & 223,7 & 228,4 & 243,9 & 233,4 & 221,4 \\
\hline Фосфрор, г & 151,1 & 154,3 & 164,7 & 157,6 & 149,2 \\
\hline Сірка, г & 56,6 & 57,8 & 61,7 & 59,0 & 55,8 \\
\hline Мідь, мг & 332,4 & 339,6 & 362,4 & 346,8 & 328,8 \\
\hline Цинк, мг & 1684,2 & 1610,3 & 1651,9 & 1404,5 & 1167,2 \\
\hline Манган, мг & 1684,2 & 1610,3 & 1651,9 & 1404,5 & 1167,2 \\
\hline Кобальт, мг & 21,6 & 24,3 & 21,1 & 17,9 & 15,1 \\
\hline Йод, мг & 30,5 & 31,1 & 33,2 & 31,8 & 30,1 \\
\hline Селен, мг & 8,31 & 8,49 & 9,06 & 8,67 & 8,22 \\
\hline Каротин, мг & 1333,9 & 1361,4 & 1453,8 & 1391,4 & 1319,1 \\
\hline Вітамін D, MO & 29300,6 & 29904,2 & 31934,3 & 30562,6 & 28972,2 \\
\hline
\end{tabular}


3 даних таблиці 2 видно, що менші дози Цинку, Мангану й Кобальту покращили споживання кормосуміші піддослідними коровами. У середньому за дослід корови 1-ї контрольної групи поїдали 53,4 кг кормосуміші, корови 2-ї дослідної групи - 54,5 кг, 3-ї - 58,2 кг, 4-ї - 55,7 кг і 5-ї - 52,8 кг.

Відповідно до даних споживання кормосуміші піддослідними коровами, найбільшу її кількість споживали корови 3-ї дослідної групи, що дало можливість отримати й найбільшу кількість поживних та біологічно-активних речовин в організм корів цієї групи.

Надходження в організм піддослідних корів у перші 100 днів лактації різних рівнів Цинку, Мангану й Кобальту за рахунок різних доз їх змішанолігандних комплексів по-різному вплинули на надої молока піддослідних корів (табл. 3).

Таблиця 3

Продуктивність дослідних корів за дослід (M $\pm \mathrm{m}, \mathrm{n=10})$

\begin{tabular}{|c|c|c|c|c|c|}
\hline \multirow{3}{*}{ Показник } & \multicolumn{5}{|c|}{ Група } \\
\hline & \multirow{2}{*}{$\begin{array}{c}\text { контрольна } \\
1 \\
\end{array}$} & \multicolumn{4}{|c|}{ дослідна } \\
\hline & & 2 & 3 & 4 & 5 \\
\hline \multicolumn{6}{|c|}{ Середньодобові надої молока за перші 100 днів лактації, кг: } \\
\hline Натуральної жирності & $50,8 \pm 0,57$ & $51,1 \pm 0,49$ & $54,7 \pm 0,42$ & $52,4 \pm 0,53$ & $48,2 \pm 0,43$ \\
\hline 4-ї жирності & $45,8 \pm 0,54^{\star *}$ & $45,7 \pm 0,42^{\star *}$ & $49,5 \pm 0,44^{* * *}$ & $47,0 \pm 0,49^{\star \star \star}$ & $43,0 \pm 0,40$ \\
\hline У \% до 5 дослідної групи & 106,51 & 106,28 & 115,12 & 109,30 & 100,0 \\
\hline Вміст жиру в молоці, \% & $3,61 \pm 0,013$ & $3,58 \pm 0,013$ & $3,62 \pm 0,015$ & $3,59 \pm 0,012$ & $3,57 \pm 0,015$ \\
\hline Вміст білку в молоці, \% & $3,32 \pm 0,022$ & $3,32 \pm 0,014$ & $3,34 \pm 0,018$ & $3,33 \pm 0,016$ & $3,31 \pm 0,017$ \\
\hline \multicolumn{6}{|c|}{ Валовий надої молока за перші 100 днів лактації, кг: } \\
\hline Натуральної жирності & $5080 \pm 56,3$ & $5110 \pm 48,5$ & $5470 \pm 40,9^{* *}$ & $5240 \pm 52,6^{* *}$ & $4820 \pm 44,2$ \\
\hline У \% до 5 дослідної групи & 106,3 & 106,2 & $113,6^{* \star}$ & $108,8^{* *}$ & 100,0 \\
\hline
\end{tabular}

Примітка: * $-P<0,5 ;{ }^{* *}-P<0,05 ;{ }^{* * *}-P<0,01$ порівняно $з$ контролем.

3 даних таблиці 3 видно, що середньодобові надої й надії молока за перші 100 днів лактації змінювалися залежно від надходження Цинку, Мангану й Кобальту до організму піддослідних корів. Найнижчі надої натурального молока за перші 100 днів лактації мали корови 5-ї дослідної групи, де концентрація мікроелементів в 1 кг СР кормосуміші була найнижчою й складала, мг: Цинку - 42,6; Мангану - 42,6 i Кобальту - 0,55. Надої натурального молока корів 1-ї контрольної, 2-ї, 3-ї й 4-ї дослідних груп були вищими від надої корів 5-ї дослідної групи на 106,3 \%, 106,2; 113,6 і 108,8 \% відповідно.

Вміст жиру в молоці корів 5-ї дослідної групи становив у середньому $3,57 \%$, тоді, як у молоці корів 1-ї контрольної, 2-ї, 3-ї й 4-ї дослідних груп він був вищим на 0,01-0,05 $\%$. У зв'язку з цим, перевага за середньодобовими надоями 4 \%-го молока була також вагомою в 1-й контрольній, 2-й, 3й і 4-й дослідних групах у порівнянні з 5-ю дослідною групою. Різниця була наступною: на 2,8 кг або 6,5 \% - у 1-й контрольній групі, на 2,7 кг або 6,3 \% - у 2-й дослідній групі, на 6,5 кг або 15,1 \% - у 3-й дослідній групі й на 4,0 кг або 9,3
- у 4-й дослідній групі.

У молоці корів вище вказаних груп порівняно з 5-ю дослідною групою однозначно зростав вміст білка - 3,32$3,34 \%$ проти $3,31 \%$.

Валовий надій молока в 5-й дослідній групі склав 4820 кг, а в 1-й контрольній та 2-й, 3-й і 4-й дослідних групах він був вищим відповідно на 260 кг, 290, 650 і 420 кг.

Таким чином, найвищі показники молочної продуктивності в перші 100 днів лактації показали корови 3-ї дослідної групи, де концентрація Цинку, Мангану й Кобальту в 1 кг СР кормосуміші була, мг: 54,7; 54,7 і 0,7 відповідно.

Одним із показників повноцінності годівлі корів є їх відтворні функції. Насамперед на відтворні функції тварин впливають біологочно активні елементи, такі як мікроелементи, вітаміни. Тому при визначенні оптимальної дози змішанолігандних комплесків Цинку, Мангану й Кобальту ми вивчали тривалість сервіс-періоди у піддослідних корів та кількість запліднень на одну голову, дані про що наведені в таблиці 4.

Показники відтворної функції у корів (M \pm m; $\mathrm{n}=10$ )

Таблиця 4

\begin{tabular}{|c|c|c|c|c|c|}
\hline \multirow{3}{*}{ Показник } & \multicolumn{5}{|c|}{ Група } \\
\hline & контрольна & \multicolumn{4}{|c|}{ дослідна } \\
\hline & 1 & 2 & 3 & 4 & 5 \\
\hline Тривалість сервіс-періоду, днів & 71,5 & 69,3 & 55,2 & 74,6 & 85,5 \\
\hline 土 до 5-ї дослідної групи: днів & $-14,0$ & $-16,2$ & $-30,3$ & $-10,9$ & - \\
\hline$\%$ & 83,6 & 81,1 & 64,6 & 87,3 & 100,0 \\
\hline Кількість запліднень на одну голову & $1,5 \pm 0,48$ & $1,6 \pm 0,43$ & $1,4 \pm 0,31$ & $1,6 \pm 0,38$ & $1,9 \pm 0,47$ \\
\hline 土 до 5-ї дослідної групи & $-0,4$ & $-0,3$ & $-0,5$ & $-0,3$ & - \\
\hline$\%$ & 78,9 & 84,2 & 73,7 & 84,2 & 100,0 \\
\hline
\end{tabular}

Дані таблиці 4 свідчать, що найбільша тривалість сервіс-періоду (85,5 днів) була у корів 5-ї дослідної групи де концентрація Цинку, Мангану й Кобальту в 1 кг СР комросуміші склала, мг: Цинку - 54,7; Мангану - 54,7 і Кобальту 0,7. Більш високі концентрації мікроелементів позитивно вплинули на тривалість сервіс-періоду і в піддослідних тварин 1-ї контрольної, 2-ї, 3-ї і 4-ї дослідної груп він був коротшим на 14,0; 16,2; 30,3 і 10,9 днів відповідно.
На одне плодотворне осіменіння кожної корови 1-ї контрольної групи знадобилось провести 1,5 запліднення, у 2-й дослідній - 1,6; у 3-й дослідній - 1,4; у 4-й дослідній - 1,6 і в 5-й дослідній - 1,9 запліднення.

Найкращі результати по відтворенню виявлені у тварин 3-ї дослідної групи, де концентрація Цинку, Мангану й Кобальту в 1 кг СР кормосуміші складала, мг: Цинку - 54,7; Мангану - 54,7 і Кобальту - 0,7. 
У діагностиці стану здоров'я тварин та обміну речовин у їх організмі важливе значення мають вміст у крові еритроцитів, лейкоцитів, гемоглобіну, білка і його фракцій, мінеральних елементів та каротину, резервна лужність, ферментативна активність тощо, тобто гематологічні показники. Як показали дослідження, істотного впливу на показники крові корів на початку досліду різні рівні змішанолігандних комплексів Цинку, Мангану й Кобальту в кормосуміші не мали, про що свідчать дані таблиці 5.

Концентрація в крові формених елементів (табл. 5) була практично однаковою в усіх корів: еритроцитів - 9,439,65 Т/л і лейкоцитів - 7,55-8,01 Г/л. Однак у дослідних корів показники були дещо вищими за показники корів 1-ї контрольної групи, за винятком 2-ї дослідної групи за концентрацією лейкоцитів.

Вміст гемоглобіну в крові корів 1-ї контрольної групи на початку досліду хоча й був високим, проте порівняно 3 дослідними групами був найнижчим і складав 107,8 г/л проти 108,2-113,4 г/л.
Щодо вмісту в крові загального білка на початку досліду, то він суттєво не відрізнявся в корів усіх піддослідних груп. Найвищим цей показник був у корів 3-ї дослідної групи, що переважав показник 1-ї контрольної групи на 7,4 \%, проте статистичної різниці не встановлено. Слід зауважити, що стартовий рівень загального білка в крові корів 2-ї дослідної групи був нижчим, ніж у корів 1-ї контрольної групи на 3,7 г/л або на 4,6 \%. Корови дослідних груп дещо відрізнялися від корів контролю і за вмістом альбумінових фракцій, проте статистичної різниці не встановлено.

Що стосується вмісту у крові неорганічного Фосфрору, Кальцію, Натрію і Калію, то вони на початку основного періоду досліду були практично однаковими в корів усіх піддослідних груп.

Оскільки відмінності між дослідними групами корів у експерименті полягали лише в кількості згодовуваних змішанолігандних комплексів Цинку, Мангану й Кобальту, було важливим з'ясувати, як саме цей фактор вплине на показники інтер'єру тварин.

Таблиця 5

Гематологічні показники піддослідних корів (n=3; $\mathrm{M} \pm \mathrm{m})$

\begin{tabular}{|c|c|c|c|c|c|}
\hline \multirow{3}{*}{ Показник } & \multicolumn{5}{|c|}{ Групи корів } \\
\hline & \multirow{2}{*}{$\begin{array}{c}\text { контрольна } \\
1\end{array}$} & \multicolumn{4}{|c|}{ дослідні } \\
\hline & & 2 & 3 & 4 & 5 \\
\hline \multicolumn{6}{|c|}{ Початок досліду } \\
\hline Еритроцити, Т/л & $9,43 \pm 0,26$ & $9,50 \pm 0,31$ & $9,65 \pm 0,24$ & $9,57 \pm 0,33$ & $9,61 \pm 0,29$ \\
\hline Лейкоцити, Г/л & $7,55 \pm 0,33$ & $7,51 \pm 0,29$ & $8,01 \pm 0,17$ & $7,57 \pm 0,22$ & $7,95 \pm 0,14$ \\
\hline Гемоглобін, г/л & $107,8 \pm 5,4$ & $108,2 \pm 3,9$ & $113,4 \pm 3,2$ & $108,8 \pm 6,2$ & $111,7 \pm 2,4$ \\
\hline Загальний білок, г/л & $80,7 \pm 1,7$ & $77,0 \pm 2,6$ & $86,7 \pm 1,8$ & $83,5 \pm 3,2$ & $79,4 \pm 2,7$ \\
\hline \multicolumn{6}{|l|}{ у тому числі: } \\
\hline альбуміни, г/л & $35,2 \pm 2,7$ & $32,4 \pm 3,1$ & $37,2 \pm 1,6$ & $36,4 \pm 2,5$ & $36,1 \pm 1,9$ \\
\hline а-глобуліни, г/л & $12,8 \pm 0,9$ & $12,3 \pm 1,5$ & $13,8 \pm 0,7$ & $13,2 \pm 1,2$ & $13,6 \pm 1,1$ \\
\hline$\beta$-глобуліни, г/л & $13,6 \pm 2,1$ & $13,7 \pm 1,8$ & $14,2 \pm 0,5$ & $13,3 \pm 1,6$ & $13,7 \pm 0,8$ \\
\hline ү-глобуліни, г/л & $19,1 \pm 1,4$ & $18,6 \pm 2,0$ & $21,5 \pm 1,2$ & $20,6 \pm 1,3$ & $17,8 \pm 1,9$ \\
\hline Неорганічний фосффор, ммоль/л & $1,42 \pm 0,04$ & $1,39 \pm 0,02$ & $1,54 \pm 0,04$ & $1,47 \pm 0,03$ & $1,49 \pm 0,01$ \\
\hline Кальцій, ммоль/л & $2,05 \pm 0,09$ & $2,09 \pm 0,05$ & $2,13 \pm 0,03$ & $2,12 \pm 0,07$ & $2,10 \pm 0,02$ \\
\hline Натрій, ммоль/л & $128,4 \pm 3,82$ & $130,2 \pm 3,95$ & $127,6 \pm 2,92$ & $129,5 \pm 2,75$ & $126,2 \pm 3,10$ \\
\hline Калій, ммоль/л & $4,91 \pm 0,25$ & $4,82 \pm 0,19$ & $4,84 \pm 0,16$ & $4,86 \pm 0,35$ & $4,82 \pm 0,14$ \\
\hline \multicolumn{6}{|c|}{ Наприкінці досліду } \\
\hline Еритроцити, Т/л & $9,63 \pm 0,15$ & $9,98 \pm 0,13$ & $10,95 \pm 0,21$ & $10,35 \pm 0,20$ & $10,17 \pm 0,14$ \\
\hline Лейкоцити, Г/л & $7,28 \pm 0,11$ & $7,31 \pm 0,08$ & $7,35 \pm 0,14$ & $7,33 \pm 0,02$ & $7,25 \pm 0,17$ \\
\hline Гемоглобін, г/л & $112,5 \pm 4,9$ & $118,4 \pm 3,8$ & $127,3 \pm 4,6^{*}$ & $124,8 \pm 3,6$ & $122,6 \pm 5,2$ \\
\hline Загальний білок, г/л & $105,5 \pm 2,3$ & $107,8 \pm 1,8$ & $111,7 \pm 0,8^{* *}$ & $108,6 \pm 1,6^{*}$ & $107,1 \pm 1,2$ \\
\hline \multicolumn{6}{|l|}{ У тому числі: } \\
\hline альбуміни, г/л & $49,2 \pm 1,8$ & $50,2 \pm 2,3$ & $53,9 \pm 2,3^{*}$ & $51,6 \pm 1,21^{*}$ & $49,5 \pm 1,9$ \\
\hline а-глобуліни, г/л & $18,7 \pm 0,9$ & $18,9 \pm 1,2$ & $18,8 \pm 1,4$ & $18,6 \pm 0,8$ & $18,2 \pm 1,0$ \\
\hline$\beta$-глобуліни, г/л & $16,9 \pm 0,6$ & $17,7 \pm 0,8$ & $17,2 \pm 1,2$ & $17,0 \pm 0,4$ & $17,0 \pm 1,1$ \\
\hline ү-глобуліни, г/л & $20,7 \pm 1,1$ & $21,0 \pm 1,0$ & $21,8 \pm 0,6^{\star *}$ & $21,4 \pm 0,9^{*}$ & $21,2 \pm 0,9$ \\
\hline Неорганічний фоссфор, ммоль/л & $1,58 \pm 0,02$ & $1,57 \pm 0,04$ & $1,67 \pm 0,18$ & $1,63 \pm 0,02$ & $1,60 \pm 0,11$ \\
\hline Кальцій, ммоль/л & $2,45 \pm 0,04$ & $2,47 \pm 0,06$ & $2,54 \pm 0,08$ & $2,50 \pm 0,03$ & $2,48 \pm 0,03$ \\
\hline Натрій, ммоль/л & $133,2 \pm 3,9$ & $135,4 \pm 5,2$ & $136,4 \pm 2,30$ & $134,5 \pm 4,7$ & $136,1 \pm 2,15$ \\
\hline Калій, ммоль/л & $5,71 \pm 0,03$ & $5,98 \pm 0,02$ & $5,86 \pm 0,09$ & $5,82 \pm 0,03$ & $4,90 \pm 0,10$ \\
\hline
\end{tabular}

Дослідження крові піддослідних корів наприкінці досліду показало, що вміст у ній еритроцитів був досить високим у всіх групах. Проте дещо більшою, хоча й статистично невірогідною ( $\mathrm{P}>0,05)$, була його різниця у крові корів 3-ї і 4-ї дослідних груп, що на 13,7 \% і 7,5 \% переважало цей показник 1-ї контрольної групи.

Водночас не виявлено міжгрупової різниці в показниках вмісту в крові корів лейкоцитів $(7,28-7,35 \cdot Г / л)$, що $€$ підставою для ствердження про відсутність запальних про- цесів в організмі піддослідних тварин.

Що стосується такого важливого показника інтер'єру, як гемоглобін, то варто відзначити, що його вміст у крові тварин усіх груп був достатньо високим - 112,5-127,3 г/л. При цьому зі зменшенням дози змішанолігандних комплексів мікроелементів в 1 кг СР кормосуміші, мг: від концентрації Цинку - 66,9; Мангану - 66,9 і Кобальту - 0,86 до концентрації Цинку - 42,6; Мангану - 42,6 і Кобальту - 0,55 зростав вміст у крові гемоглобіну. Різниця в порівнянні з тваринами 
1-ї контрольної групи склала відповідно 5,2 \%, 13,2 (P<0,05), 10,9 та $9,0 \%$.

Досліджуваний нами фактор мав відповідний вплив на вміст у крові корів загального білка. Хоча цей показник і був високим у всіх тварин, проте корови 3-ї і 4-ї дослідних груп переважали аналогів 1-ї контрольної групи відповідно на $5,9 \%(P<0,01)$ і $2,9 \%(P<0,05)$. Відповідно до загального білка в крові корів 3-ї і 4-ї дослідних груп порівняно з тваринами 1-ї контрольної групи збільшувався також вміст фракцій білка, зокрема альбумінів на 4,7 і 2,4 г/л, або 9,6 і 4,9% $(P<0,05)$.

Вміст фракцій а-глобулінів у корів дослідних груп корів був на одному рівні з тваринами контрольної групи. Що стосується ß-глобулінової фракції, то в крові корів 2-ї - 5-ї дослідних груп цей показник перевищував показник корів контрольної групи відповідно на 0,1-0,6 г/л, або 0,5-4,7\% $(\mathrm{P}<0,05)$. Щодо показника вмісту в загальному білку фракцій ү-глобулінів, то корови всіх дослідних груп переважали контрольних аналогів відповідно на 0,3-1,1 г/л або 1,4-5,3 $\%$. Що ймовірно пов'язане зі зменшенням доз згодовування змішанолігандних комплексів Цинку, Мангану й Кобальту від концентрації в 1 кг СР кормосуміші, мг: Цинку - 66,9; Мангану - 66,9 і Кобальту - 0,86 до концентрації Цинку - 42,6; Мангану - 42,6 і Кобальту - 0,55 та зумовлювало тенденцію до зменшення фрракції альбумінів i, навпаки, зростання үглобулінової фракції, що відповідає за резистентність організму.

Різні рівні змішанолігандних комплексів Цинку, Мангану й Кобальту в раціоні не мали суттєвого впливу на вміст у крові корів неорганічного Фосфору (1,58-1,67 ммоль/л), Кальцію (2,45-2,54 ммоль/л), Натрію (133,2-136,4 ммоль/л) і Калію (5,71-5,98 ммоль/л).

Висновки. Аналіз гематологічних показників піддослідних корів свідчить, що змішанолігандні комплекси Цинку, Мангану й Кобальту у складі концентрованих кормів позитивно впливають на організм лактуючих корів, поліпшуючи їхню продуктивність і, особливо, відтворні функції. Найефективнішою виявилась доза змішанолігандних комплексів Цинку, Мангану й Кобальту з концентрацією в 1 кг СР кормосуміші, мг: Цинку - 54,7; Мангану - 54,7 і Кобальту - 0,7.

\section{Список використаної літератури:}

1. Довідник по застосуванню біологічно активних речовин у тваринництві. / В. Ю. Чумаченко та ін. Київ : Урожай, 1989. 262 c.

2. Богданов Г. О., Ібатуллін І. І., Кандиба В. М. Концептуальні положення удосконалених норм годівлі високопродуктивної молочної худоби в Україні. Актуальні проблеми годівлі тварин і технології кормів : матеріали Міжнар. наук.-практ. конф. Київ, 2008. С. 14-18.

3. Довгій Ю. Ю., Сеніченко В. Ю., Фещенко Д. В., Чала І. В. Вплив вітамінно-мінеральних комплексів на молочну продуктивність та гематологічні показники корів. Вісник ПДАА. 2019. № 2. С. 85-91.

4. Ibatullin I. I., Holubiev M. I. Effect of feeds containing different sources of manganese on certain carcass parameters of quail. Scientific Messenger of Lviv National University of Veterinary Medicine and Biotechnology named after S.Z. Gzhytsky, 2017. 19(79), 13-16. doi:10.15421/nvlvet7903

5. Cows make a lasting impression in these herds. Hoards dairyman. 1995. V. 140. № 1. P. 10-11.

6. Воробель М. І., Півторак Я. І. Значення мікроелементів у життєдіяльності тварин. Науковий вісник ЛНУВМ та БТ ім. С.3. Ґжицького, 2011. Т. 13, № 4 (50), ч. 3. С 54-60.

7. Milk fatty acid composition and mammary lipid metabolism in Holstein cows fed protected or unprotected canola seeds $/$ [Delbecchi L., Ahnadi C., Kennelly J., Laccasse P.] // J. Dairy Sci. 2001. Vol. 84, № 6. P. 1375-1381.

8. Hackbart K. S., Ferreira R. M., Dietsche A. A., Socha M. T., Shaver R. D., Wiltbank M. C., \& Fricke, P. M. (2010). Effect of dietary organic zinc, manganese, copper, and cobalt supplementation on milk production, follicular growth, embryo quality, and tissue mineral concentrations in dairy cows. Journal of Animal Science, 88 (12), 3856-3870. doi:10.2527/jas.2010-3055.

9. Fisher L. I., Peterson Y. B., lones S. E. Shelford L. A. Two housing systems for calves. Dairy Sci. 1985.

10. Kropyvka Yu., Bomko V. Efficiente of use premixes on the basis of metal chelates in feeding cows in the first 100 days of lactation. Scientific Messenger of Lviv National University of Veterinary Medicine and Biotechnology named after S.Z. Gzhytsky, 2017, vol. 19 (79), pp. 154-158.

11. Hackbart K. S., Ferreira R. M., Dietsche A. A., Socha, M. T., Shaver, R. D., Wiltbank, M. C., \& Fricke, P. M. (2010). Effect of dietary organic zinc, manganese, copper, and cobalt supplementation on milk production, follicular growth, embryo quality, and tissue mineral concentrations in dairy cows. Journal of Animal Science, 88 (12), 3856-3870. doi:10.2527/jas.2010-3055.

12. Засєкін Д. А. Моніторинг важких металів у довкіллі та способи їх зниження в організмі тварин : дис. ... д-ра вет. наук / Нац. агр. ун-т. Київ, 2002. 354 с.

13. Кравців Р. Й., Буцяк В. І. Продуктивність та обмін речовин у лактуючих корів за різного вмісту важких металів у раціонах. Вісник аграрної науки. 2004. № 1. С. 29-31.

14. Levitskaya, L.G. (2017). The needs and characteristics of feeding dairy cows. Scientific Messenger of Lviv National University of Veterinary Medicine and Biotechnology named after S.Z. Gzhytsky, 19(79), 62-67. doi:10.15421/nvlvet7913

20. C. $53-58$.

15. Петриченко О. А., Петриченко І. І. Організація кормозабезпечення молочного скотарства. Агросвіт. 2017. № 19-

16. De Frain, J. M., Socha, M. T., Tomlinson, D. J., \& Kluth, D. (2009). Effect of Complexed Trace Minerals on the Performance of Lactating Dairy Cows on a Commercial Dairy. The Professional Animal Scientist, 25 (6), 709-715. doi:10.15232/s10807446(15)30779-8.

\section{References:}

1. Dovidnyk po zastosuvannju biologichno aktyvnyh rechovyn u tvarynnyctvi [Handbook on the use of biologically active 
substances in animal husbandry]. V. Ju. Chumachenko ta in. Kyi'v : Urozhaj, 1989. 262.

2. Bogdanov, G. O., Ibatullin, I. I. and Kandyba, V. M., 2008. Konceptual'ni polozhennja udoskonalenyh norm godivli vysokoproduktyvnoi' molochnoi' hudoby v Ukrai'ni [Conceptual provisions of improved norms of feeding highly productive dairy cattle in Ukraine]. Aktual'ni problemy godivli tvaryn i tehnologii' kormiv : materialy Mizhnar. nauk.-prakt. konf. Kyi'v, pp. 14-18.

3. Dovgij, Ju. Ju., Senichenko, V. Ju., Feshhenko, D. V. and Chala, I. V., 2019. Vplyv vitaminno-mineral'nyh kompleksiv na molochnu produktyvnist' ta gematologichni pokaznyky koriv [Influence of vitamin-mineral complexes on milk productivity and hematological parameters of cows]. Visnyk PDAA, no. 2, pp. 85-91.

4. Ibatullin, I. I. and Holubiev, M. I., 2017. Effect of feeds containing different sources of manganese on certain carcass parameters of quail. Scientific Messenger of Lviv National University of Veterinary Medicine and Biotechnology named after S.Z. Gzhytsky, issue 19(79), pp. 13-16. doi:10.15421/nvlvet7903

5. Cows make a lasting impression in these herds. Hoards dairyman. 1995. issue 140, no. 1, pp. 10-11.

6. Vorobel', M. I. and Pivtorak, Ja. I.. 2011. Znachennja mikroelementiv u zhyttjedijal'nosti tvaryn [The value of trace elements in animal life]. Naukovyj visnyk LNUVM ta BT im. S.3. G'zhyc'kogo, T. 13, no. 4 (50), ch. 3. pp. 54-60.

7. Delbecchi, L., Ahnadi, C., Kennelly, J., Laccasse P., 2001. Milk fatty acid composition and mammary lipid metabolism in Holstein cows fed protected or unprotected canola seeds. J. Dairy Sci, vol. 84, issue 6, pp. 1375-1381.

8. Hackbart, K. S., Ferreira, R. M., Dietsche, A. A., Socha, M. T., Shaver, R. D., Wiltbank, M. C., and Fricke, P. M., 2010. Effect of dietary organic zinc, manganese, copper, and cobalt supplementation on milk production, follicular growth, embryo quality, and tissue mineral concentrations in dairy cows. Journal of Animal Science, issue 88 (12), pp. 3856-3870. doi: 10.2527/jas.20103055 .

9. Fisher, L. I., Peterson, Y. B., lones, S. E. and Shelford, L. A., 1985.Two housing systems for calves. Dairy Sci.

10. Kropyvka, Yu. and Bomko, V., 2017. Efficiente of use premixes on the basis of metal chelates in feeding cows in the first 100 days of lactation. Scientific Messenger of Lviv National University of Veterinary Medicine and Biotechnology named after S.Z. Gzhytsky, vol. 19 (79), pp. 154-158.

11. Hackbart, K. S., Ferreira, R. M., Dietsche, A. A., Socha, M. T., Shaver, R. D., Wiltbank, M. C. and Fricke, P. M., 2010. Effect of dietary organic zinc, manganese, copper, and cobalt supplementation on milk production, follicular growth, embryo quality, and tissue mineral concentrations in dairy cows. Journal of Animal Science, issue 88 (12), pp. 3856-3870. doi:10.2527/jas.20103055 .

12. Zasjekin, D. A., 2002. Monitoryng vazhkyh metaliv u dovkilli ta sposoby i'h znyzhennja v organizmi tvaryn [Monitoring of heavy metals in the environment and ways to reduce them in animals] : dys. ... d-ra vet. nauk / Nac. agr. un-t. Kyi'v, 354.

13. Kravciv, R. J., and Bucjak, V. I., 2004. Produktyvnist' ta obmin rechovyn u laktujuchyh koriv za riznogo vmistu vazhkyh metaliv u racionah [Productivity and metabolism in lactating cows with different content of heavy metals in the diet]. Visnyk agrarnoi' nauky. № 1. pp. 29-31.

14. Levitskaya, L.G., 2017. The needs and characteristics of feeding dairy cows. Scientific Messenger of Lviv National University of Veterinary Medicine and Biotechnology named after S.Z. Gzhytsky, 19(79), 62-67. doi:10.15421/nvlvet7913

15. Petrychenko, O. A. and Petrychenko, I. I., 2017. Organizacija kormozabezpechennja molochnogo skotarstva [Organization of fodder supply for dairy cattle]. Agrosvit, no. 19-20, pp. 53-58.

16. De Frain, J. M., Socha, M. T., Tomlinson, D. J. and Kluth, D., 2009. Effect of Complexed Trace Minerals on the Performance of Lactating Dairy Cows on a Commercial Dairy. The Professional Animal Scientist, issue 25 (6), pp. 709-715. doi: 10.15232/s1080-7446(15)30779-8.

Kropyvka Yurij Grygorovych, PhD of Agricultural Sciences, Docent, Stepan Gzhytskyi National University of Veterinary Medicine and Biotechnologies (Lviv, Ukraine)

Bomko Vitalij Semenovych, Doctor of Agricultural Sciences, Professor, Bila Tserkva National Agrarian University (Bila Tserkva, Ukraine)

Different levels of mixed-ligande complexes of Zinc, Manganese and Cobalt in the feeding of highlyproductive Holstein cows of German selection and their impact on feed consumption, productivity, feed consumption, reproductive function and hematological parameters.

The article presents the results of studying the effect of different doses of mixed-ligande complexes of Zinc, Manganese and Cobalt in feeding high-yielding Holstein cows of German selection on feed consumption, milk productivity for the first 100 days of lactation, reproductive function and hematological parameters. It was found that lower doses of Zinc, Manganese and Cobalt improved feed intake by experimental cows. On the average for experiment of cows of the $1 \mathrm{st}$ control group ate $53.4 \mathrm{~kg}$ of a forage mix, cows of the 2nd experimental group $-54.5 \mathrm{~kg}$, 3rd $-58.2 \mathrm{~kg}, 4 \mathrm{th}-55.7 \mathrm{~kg}$ and $5 \mathrm{th}-52.8 \mathrm{~kg}$. The average daily milk yield and milk yield for the first 100 days of lactation varied depending on the intake of Zinc, Manganese and Cobalt to the body of experimental cows. The lowest milk yields of natural milk for the first 100 days of lactation were cows of the 5th experimental group, where the concentration of trace elements in $1 \mathrm{~kg}$ of DM feed was the lowest and was, $\mathrm{mg}$ : Zinc - 42.6; Manganese - 42.6 and Cobalt 0.55. The milk yield of natural milk of cows of the 1st control, 2nd, 3rd and 4th experimental groups was higher than the milk yield of cows of the 5th experimental group by $106.3 \%, 106.2 ; 113.6$ and $108.8 \%$, respectively. The fat content in the milk of cows of the 5th experimental group averaged $3.57 \%$, while in the milk of cows of the 1st control, 2nd, 3rd and 4th experimental groups it was higher by $0.01-0.05 \%$. Higher concentrations of trace elements had a positive effect on the duration of the service period and in the experimental animals of the 1st control, 2nd, 3rd and 4th experimental groups, it was shorter by 14.0; 16.2; 30.3 and 10.9 days, respectively. One fertile insemination of each cow of the 1 st control group required 1.5 inseminations, in the 2nd experimental - 1.6; 
in the 3rd experimental - 1.4; in the 4th experimental - 1.6 and in the 5th experimental - 1.9 fertilization. Analysis of hematological parameters of experimental cows shows that mixed-ligande complexes of Zinc, Manganese and Cobalt in concentrated feeds have a positive effect on the body of lactating cows, which, in turn, improves their productivity and especially reproductive functions. The most effective was the dose of mixed-ligande complexes of Zinc, Manganese and Cobalt with a concentration of $1 \mathrm{~kg}$ of DM feed mixture, mg: Zinc - 54.7; Manganese - 54.7 and Cobalt - 0.7.

Key words: highlyproductive cows, milk productivity, reproductive function, hematological parameters, microelements, mixed-ligande complexes.

Дата надходження до редакції: 26.11.2020 р. 